\title{
TELESTES SOUFFIA (RISSO, 1827) SPECIES CONSERVATION AT THE EASTERN LIMIT OF RANGE - VIŞEU RIVER BASIN, ROMANIA
}

\author{
CURTEAN-BĂNĂDUC, A. $.^{*}-$ DIDENKO, A. ${ }^{2}-$ GUTI, G. ${ }^{3}-$ BĂNĂDUC, D. ${ }^{4 *}$ \\ ${ }^{1}$ Applied Ecology Research Centre, "Lucian Blaga" University of Sibiu \\ Dr. Ion Raţiu Street 5-7, 550012 Sibiu, Sibiu County, Romania \\ ${ }^{2}$ Institute of Fisheries of the National Academy of Agrarian Sciences of Ukraine \\ Obukhivska Str. 135, 03164 Kiev, Ukraine
}

${ }^{3}$ Danube Research Institute, Centre for Ecological Researches, Hungarian Academy of Sciences Karolina u. 29, 1113 Budapest, Hungary

${ }^{4}$ Faculty of Sciences, "Lucian Blaga" University of Sibiu

Dr. Ion Raţiu Street 5-7, 550012 Sibiu, Sibiu County, Romania

*Corresponding author

e-mail: ad.banaduc@yahoo.com; phone: +40-722-604-338

(Received 22 $2^{\text {nd }}$ Jun 2017; accepted $8^{\text {th }}$ Nov 2017)

\begin{abstract}
The aim of this study implemented in 2011-2016 was to assess the status of Telestes souffia (Risso, 1827) and its habitats in its extreme eastern limit, a small island-like area in the upper Tisa Basin including the Vişeu Basin, which was under a long term significant human impact. The survey was based on electrofishing at 370 sampling stations for fish sampling and mapping. There where $T$. souffia was found, the habitats quality were assessed, and the causes of the identified situation were described. The studied lotic habitats are large enough, but their quality is mostly mediocre and occasionally reduced due to: poaching, riverbed morphodynamic changes, disruption of water and sediment flow, destruction of riparian vegetation, habitat fragmentation, organic pollution, and flood washing of fish. The main finding is that the effects of the identified human impact induced a moderate decrease of $T$. souffia distribution. Specific management elements were suggested in order to offer amelioration of the decreasing trend of the studied species, and for its long term survival in this sensitive zoogeographical isolated area. Integrated future monitoring and management of the basin are the main corner stones needed for this extreme population of $T$. souffia to survive and thrive.
\end{abstract}

Keywords: Vairone, fish ecology, riparian ecosystem, isolation, conservation, management

\section{Introduction}

The Telestes souffia (Risso, 1827) (Actinopterygii, Cypriniformes, Cyprinidae) (Code Natura 2000: 1131/6147) geographical distribution includes an extreme eastern small island-like area in the upper Tisa River at the Romanian-Ukrainian border (Bănărescu, 1964; Ardelean and Beres, 2000; Bănărescu and Bănăduc, 2007) including the Vişeu River basin, which was under a constant and significant human impact in the last half of the $20^{\text {th }}$ century (Staicu et al., 1998; Curtean-Bănăduc, 2008; CurteanBănăduc et al., 2014). The local ichthyofauna status including the survival of the $T$. souffia in this isolated part of its distribution area depends in general on human activities (Bănărescu, 2005), and the different categories of human impact which have significant effects on this species should be identified and inventoried. This paper proposes to make this work and also to offer some management elements for the studied basin, with special regards to the $T$. souffia. 
A rather great variety of habitats and their species of conservation interest in the Vişeu Basin, including fish, are indubitable valuable (Bănărescu, 1964; Staicu et al., 1998; Ardelean and Beres, 2000; Curtean-Bănăduc et al., 2008). Around 50\% of the fish species sampled in the Vișeu River basin are of important conservation interest: Eudontomyzon danfordi (Regan, 1911), Thymallus thymallus (Linnaeus, 1758), T. souffia (Risso, 1827), Romanogobio uranoscopus (Agassiz, 1828), Barbus meridionalis (Risso, 1827), Sabanejewia aurata (De Filippi, 1863), Cottus gobio (Linnaeus, 1758), and Hucho hucho (Linnaeus, 1758).

T. souffia is under the protection of the Bern Convention (at which Romania joined through the Law 13 of 1993), the European Directive 92/43/EEC Annex II, O.U.G. 57/2007/Law 49/2011 of the Romanian Government concerning the protected areas, habitats conservation, and of wild fauna and flora. This species is also listed in the Red Book of Ukraine as vulnerable (Akimov, 2009) and it is a critically endangered species in Hungary (Guti et al., 2014).

The studied species inhabits middle reaches of streams and rivers in the grayling ichthyologic zone, in general in the sectors with clear and moderate-fast flowing water, on gravel bottom. The required spawning habitats are rocky fast flowing sectors and its food consists of insect larvae, rheophilic crustaceans, algae and diatoms. It can reach 20 $\mathrm{cm}$ in length. The abundance of this species decreased in the second half of the 20 century in the studied area, the human impact has an important role (Bănărescu, 1964; Kottelat and Freyhof, 1972).

In the context in which the Vişeu Basin faced significant human pressures as a whole, with negative impacts on different fish species (Staicu et al., 1998), the central needed objective of this study was to assess the distribution and ecological status of the locally threatened $T$. souffia in one of its small isolated areas of distribution in the Eastern Carpathians (Romania), and the particular results to propose specific in situ management elements for the studied populations.

The identification and mapping of human pressures form the frame for in situ management of $T$. souffia studied populations.

\section{Material and methods}

The study on mapping and assessment of the $T$. souffia conservation status, or the identification of anthropogenic elements that can disturb this fish species in the Vişeu River basin, was carried out in 2011-2016 at 370 sampling stations (Fig. 1, Table 1). The following elements were evaluated in all 370 sampling stations: human pressures on habitats, habitat state, and presence of $T$. souffia populations.

To assess the spatial distribution and ecological condition of the Vişeu River basin $T$. souffia population, in the context of this species conservation value, biological samples were taken in the studied area from around two to three kilometres between two successive sampling stations along the Vişeu River and its tributaries. The sampled lotic sectors of the studied basin were selected for their appropriate/possible habitats for the fish species of interest. Additional sampling stations were done upstream from the last appropriate habitat for this fish species in order to acquire a good coverage of the studied basin. This setting of the sampling stations, based on the authors field experience during a quarter of a century in this basin of interest, guarantees the appropriateness of the obtained data and recognition of the modifications in the target fish species population under the human induced habitat changes. 


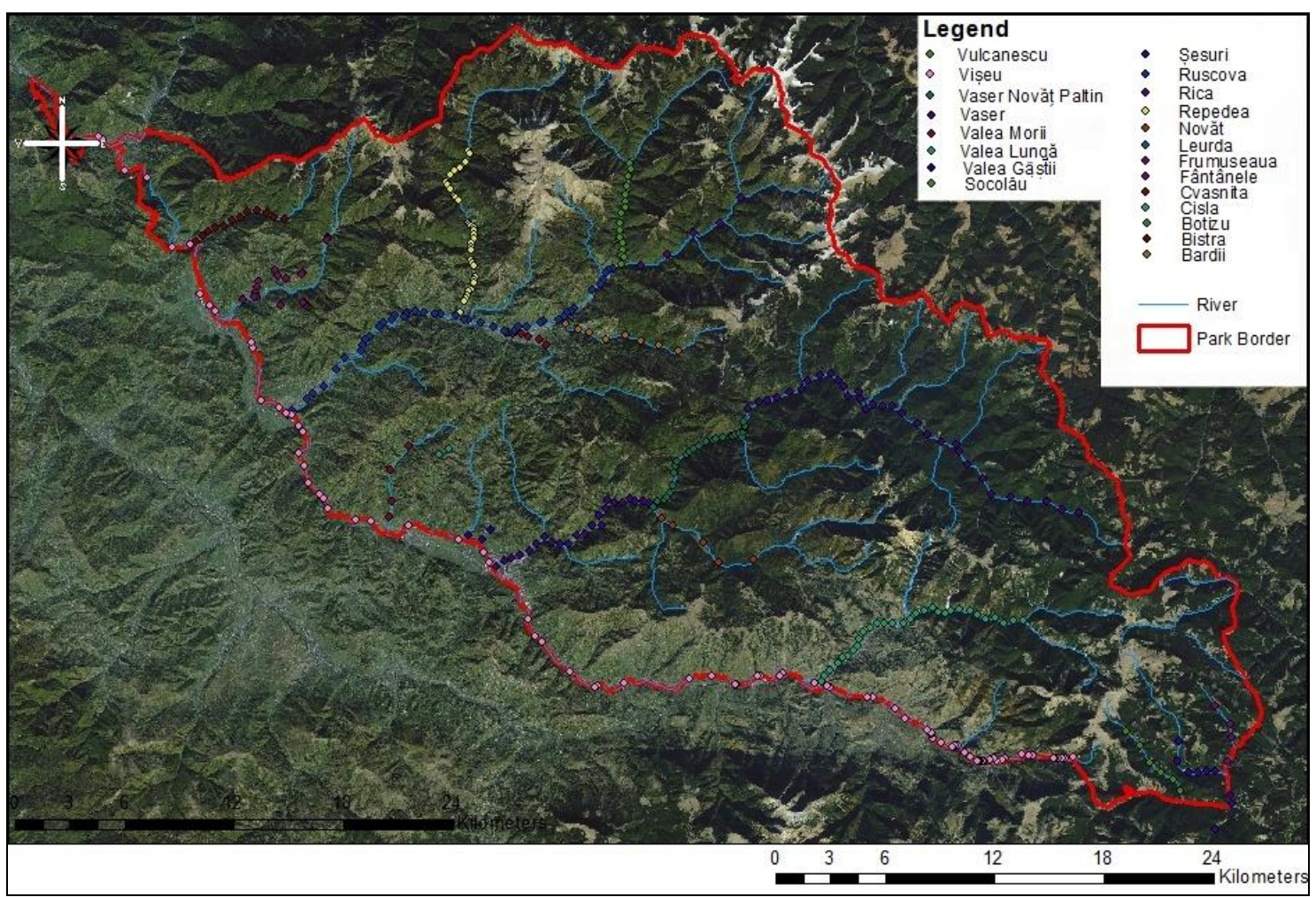

Figure 1. The location of the 370 sampling stations in the studied area

Table 1. Telestes souffia sampling sites in the Vişeu River basin

\begin{tabular}{|l|c|c|c|c|c|c|}
\hline $\begin{array}{l}\text { No. } \\
\text { crt. }\end{array}$ & River & $\begin{array}{c}\text { Station } \\
\text { code }\end{array}$ & Lat. (N') & Long. (E') & $\begin{array}{c}\text { Catch index no. ind./time } \\
\text { unit (3 h in Vişeu River } \\
\text { and 2 h in Vişeu } \\
\text { tributaries) }\end{array}$ & $\begin{array}{c}\text { Characteristic } \\
\text { habitat state }\end{array}$ \\
\hline 1. & Vișeu & 60 & 474501.0 & 241720.7 & 1 & Reduced \\
\hline 2. & Vișeu & 66 & 474701.2 & 241615.4 & 1 & Reduced \\
\hline 3. & Vișeu & 70 & 474904.9 & 241445.1 & 1 & Average \\
\hline 4. & Vișeu & 77 & 475400.7 & 240906.6 & 6 & Average \\
\hline 5. & Vișeu & 78 & 475453.1 & 240807.9 & 2 & Average \\
\hline 6. & Vișeu & 79 & 475458.2 & 240755.3 & 3 & Average \\
\hline 7. & Ruscova & 9 & 474953.9 & 242829.3 & 1 & Reduced \\
\hline 8. & Ruscova & 11 & 474944.7 & 242734.0 & 1 & Reduced \\
\hline 9. & Ruscova & 20 & 474942.0 & 242448.1 & 3 & Average \\
\hline 10. & Ruscova & 27 & 474959.8 & 242158.4 & 9 & Average \\
\hline 11. & Ruscova & 31 & 474952.0 & 242101.0 & 2 & Average \\
\hline 12. & Ruscova & 35 & 474916.9 & 241968.1 & 1 & Average \\
\hline 13. & Vaser & 43 & 474336.4 & 242926.9 & 1 & Average \\
\hline 14. & Vaser & 47 & 474319.6 & 242759.3 & 4 & Average \\
\hline 15. & Vaser & 49 & 474319.9 & 242717.8 & 1 & Average \\
\hline 16. & Novăț & 31 & 474715.4 & 243635.0 & 1 & Average \\
\hline
\end{tabular}


The quantitative fish sampling was carried out by catch per unit effort (CPUE) of electrofishing. Five longitudinal lotic sectors of one $\mathrm{km}$ in length for three hours on the Vişeu River and for two hours in the tributaries, were researched. All specimens of $T$. souffia (green spots in Fig. 2) were released on their habitat.

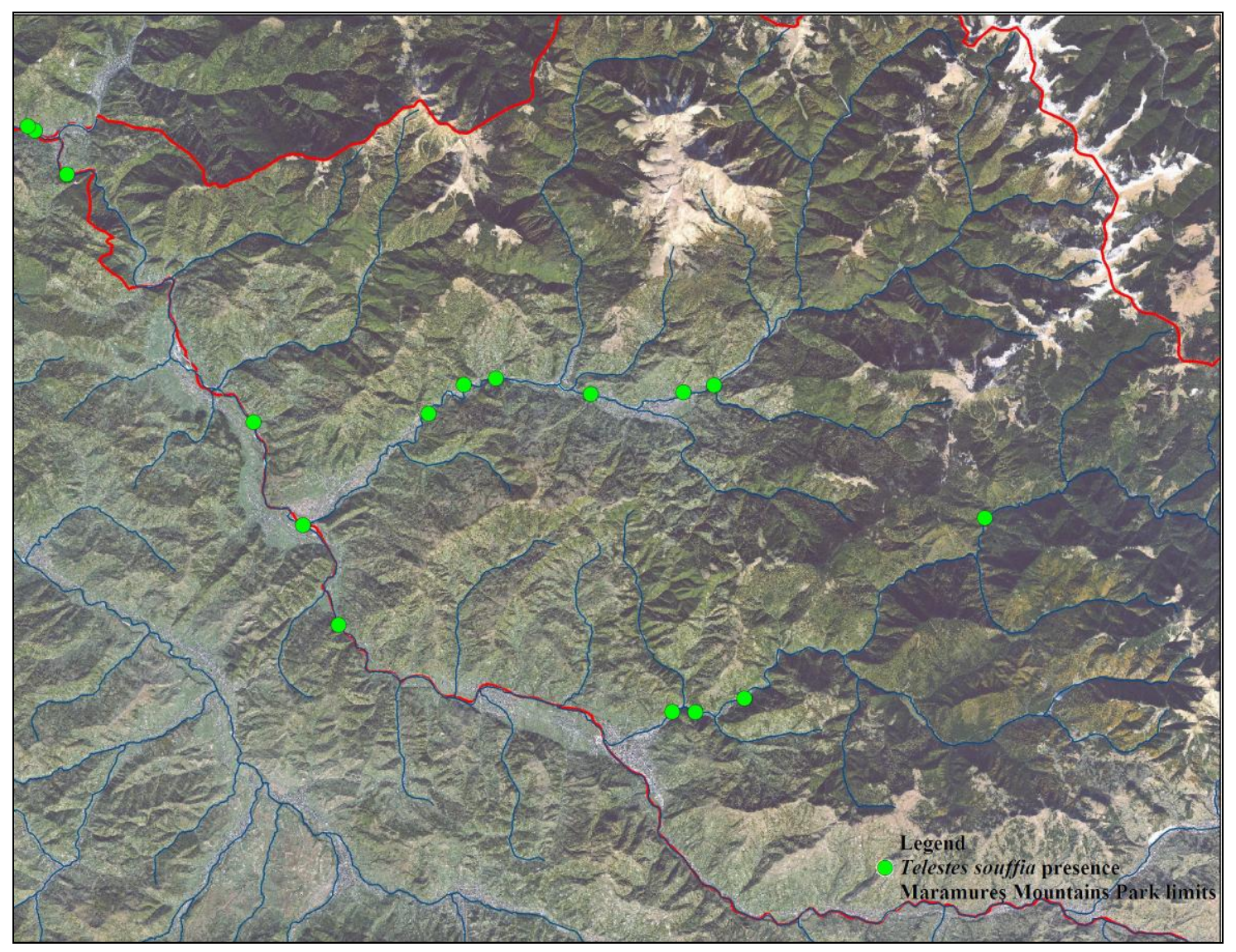

Figure 2. The sampling stations, where Telestes souffia were observed

The CPUE can be transformed through the correspondence in different categories: $(\mathrm{C})-$ common species, (R) - rare, or (V) - very rare according to the Natura 2000 standard data form guidelines, "In mammals, amphibians, reptiles and fishes, no numeric information can be indicative and then the size/density of the population is evaluated as $(\mathrm{C})-$ common, $(\mathrm{R})-$ rare, or (V) - very rare".

The criteria used to assess $T$. souffia population status are the following: 1) equilibrated allocation of fish by age categories, 2) the size of population, 3) the size of distribution area and 4) the relative percentage of individuals of the fish species of interest in the fish communities.

According to the Natura 2000 guidelines, the criteria "The conservation degree of specific habitats" in the standard data form incorporate two subcriteria: i) degree of conservation of habitat features, which are important for the species; ii) recovery possibilities.

The criteria i) need an all-encompassing assessment of habitat characteristic concerning the necessities of the species of concern. "The best expertise" way of dealing with the issue was used to rank this criterion in the following elements: I in excellent condition, II well preserved, III in moderately/partially degraded. 
When the subclass I is accepted "I elements in excellent condition" or "II well preserved elements," the criteria B (b) should be classified completely as "A: excellent conservation" or "B: good conservation", indifferent of the other sub-criterion classification. The criteria ii) which can be use only if the items are degraded moderately or partially, an assessment of the viability of the studied population is needed. The acquired ranking system is: I easy recovery; II possible restoration with moderate effort; III restoration is or difficult or impossible.

The synthesis applied for classification is based on two sub-criteria: A-excellent conservation $=$ excellent condition $;$ B-good conservation $=$ well preserved elements; $\mathrm{C}$ average or reduced conservation $=$ all other combinations.

\section{Result and discussion}

The running lotic sections where this fish species (Fig. 3) was sampled during this study are presented in Table 1; the catch index values were detailed for each sampling section (fish individuals number per time and unit effort).

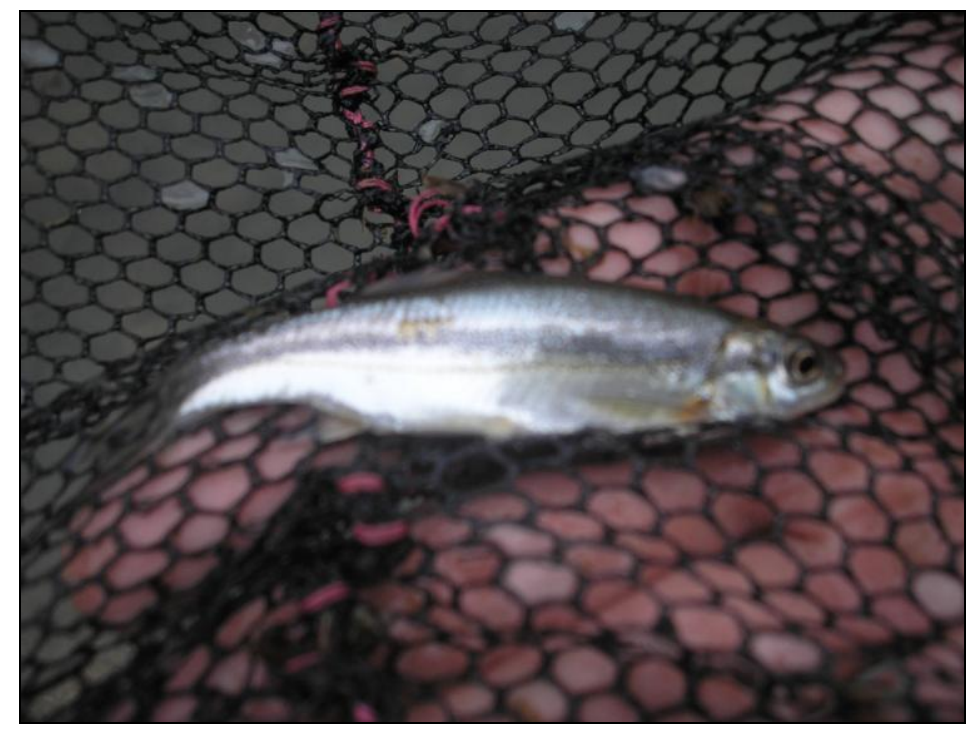

Figure 3. Sampled Telestes souffia

Within the studied area, T. souffia form permanent populations in the Vișeu River and some of the tributaries such as Ruscova, Vaser, and Novăţ. The studied habitats of this fish species are large enough, but their quality is mostly mediocre and occasionally reduced (Table 1, Figures 4 and 5), with good perspective for long term survival of this species in the studied area.

The identified types of human pressures in the studied area have a long term medium cumulative result, affecting somewhat the long-term ecological status of the T. souffia.

Based on this field data, some risk elements related to the biological and ecological requirements of $T$. souffia were identified as pressures and threats: poaching, minor changes in riverbed morphodynamics due to river engineering; disruption of water flow and natural sediment transport; destruction of riparian tree and shrub vegetation; habitat fragmentation/isolation of fish populations; organic pollution; flood washing of fish (Figs. 4 and 5). 


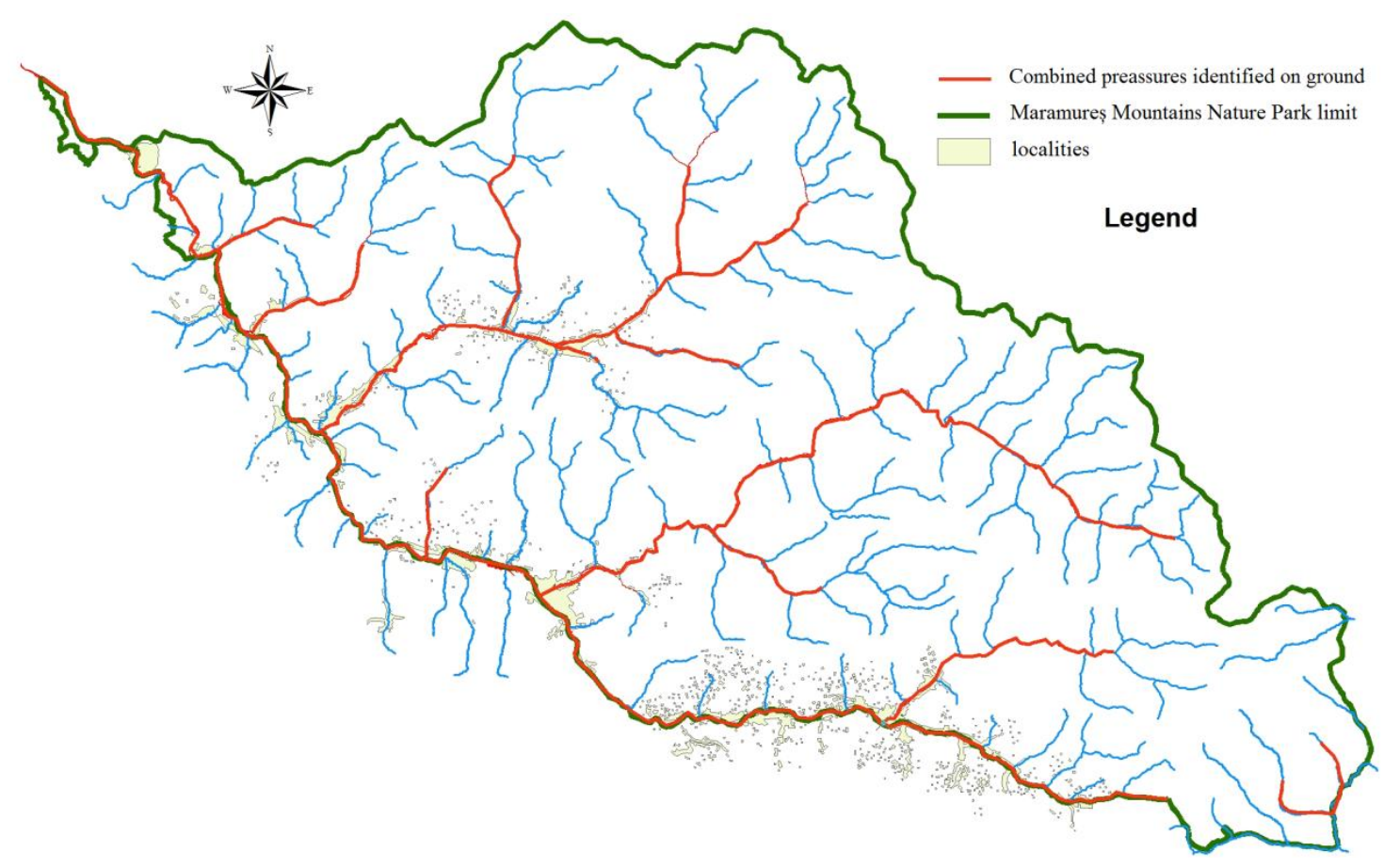

Figure 4. Identified (in red) combined pressures (poaching, minor changes in riverbed morphodynamics due to river engineering, disruption of water flow and natural sediment transport, destruction of riparian tree and shrub vegetation, habitat fragmentation/isolation of fish populations, flood washing of fish) on Telestes souffia

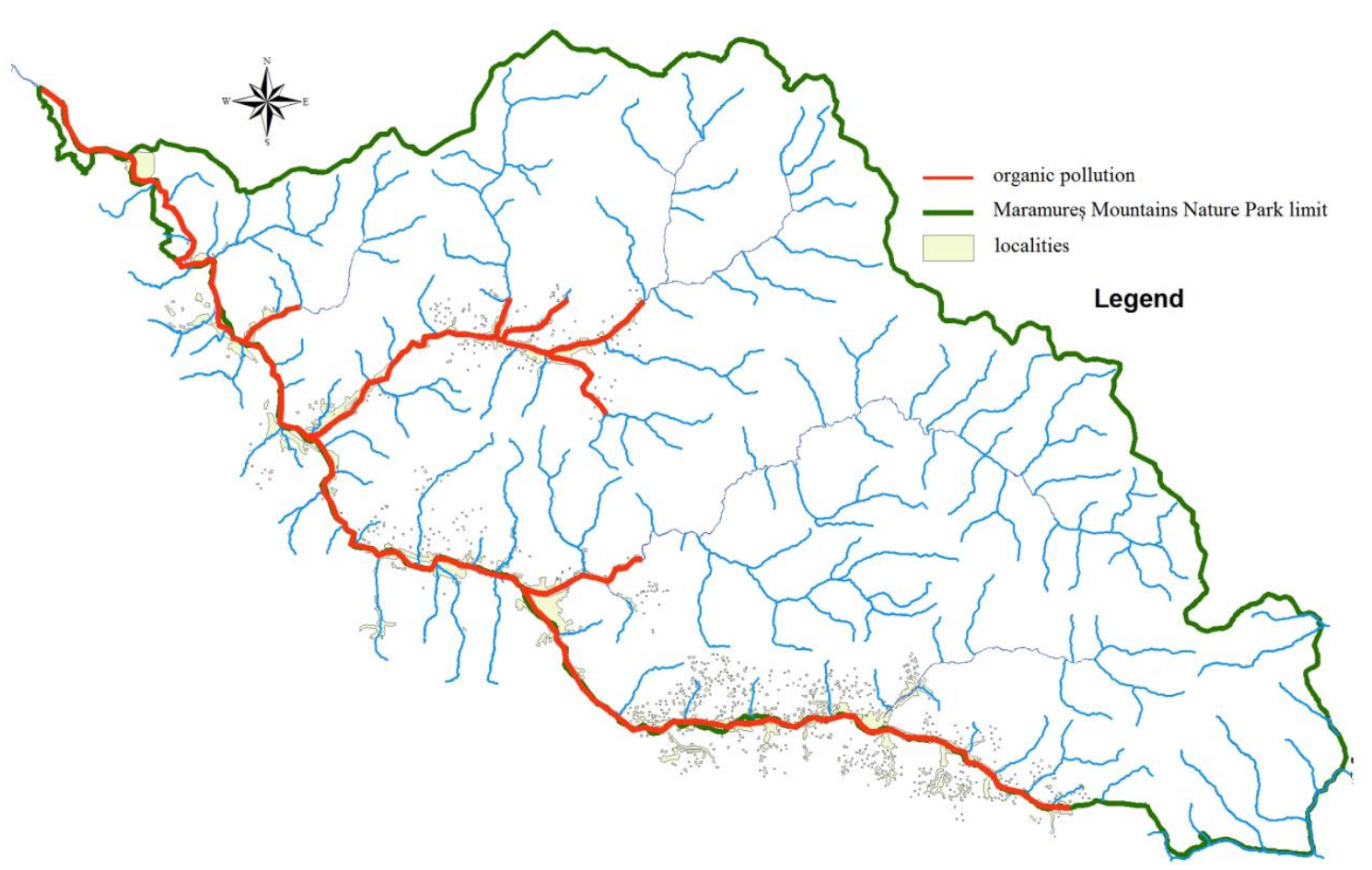

Figure 5. Identified organic pollution (in red) sectors as pressure on Telestes souffia 


\section{Poaching}

During the study, poaching activities (in over $20 \%$ of our field sampling activities) with the use of electrofishing devices were noted. Sometimes, poachers were observed to use diverse substances for fishing. By interviewing 431 local people in the Vişeu River basin, it is obvious that poaching is an usual activity here, and these illegal actions induce a significant decrease in the $T$. souffia population. $T$. souffia is not a targeted species for poachers due to its small size, but non-selective poaching activities endanger this species too. $T$. souffia also occurs in poacher's catches done by a variety of illegal fishing techniques in the neighbouring Transcarpathian region of Ukraine, where poaching is also quite a common activity (Didenko et al., 2011; 2014).

\section{Minor changes in riverbed morphodynamics due to river engineering}

$T$. souffia has relatively diverse habitat requirements, including different natural processes of riverbed morphology. Dams, dykes, sills, roads in riverbeds, sediment transport modification, gravel excavation (Fig. 5), etc., have significant impacts on natural morphodynamics of the riverbed and therefore the $T$. souffia key habitats are damaged, a fact that induces a decrease in the population size. On the other hand, this species avoids places with very fast currents and can be often found in pools near barrages, small dams, hydrotechnical facilities, etc. (Danko, 1956) and therefore their construction can create favourable conditions for $T$. souffia.

\section{Disruption of water flow and natural sediment transport}

The unnatural water flow and sediment transport create unfavourable circumstances for forming of the needed key habitats for different fish species in the studied basin, and these processes may induce fish population decline (Bănăduc, 2008). The boost of the turbidity of water due to negligent forestry activities is only one case of the elements resulting in the modification of the natural sediment transport in the rivers.

\section{Destruction of riparian tree and shrub vegetation}

Destruction of riparian tree and shrub vegetation and therefore reduction of the riverine vegetation (Fig. 6), by fractional/total destruction, both in the context of depreciating the microclimate protection and that of trophic resources, can lead to a reduction in abundance of fish fauna, including $T$. souffia populations. The shrubby and woody riparian vegetation should be as intact as possible for a minimum of 5-10 m width in the upper part of the studied rivers and of 10-25 m width in their lower part (Curtean-Bănăduc et al., 2014).

\section{Habitat fragmentation/isolation of fish populations}

Habitat fragmentation/isolation of fish populations often creates the situations of fish genetic isolation, reduction of genetic diversity resulting in inbreeding and local extinction (Popa et al., 2016). Interruption of streams and rivers by dams restricts longitudinal migration of $T$. souffia and its access it's to key habitats, which can induce a decrease in the abundance and finally to the disappearance of this fish species. 


\section{Organic pollution}

Organic pollution from municipal sewage systems, aquaculture and riverine agriculture is a persistent problem in the most part of the Vișeu River basin, mainly along the Vișeu River (Staicu et al., 1998), which affect the T. souffia populations. Comprehensive development of the sewage systems and the wastewater treatment are urgent tasks everywhere in the Vișeu Basin.

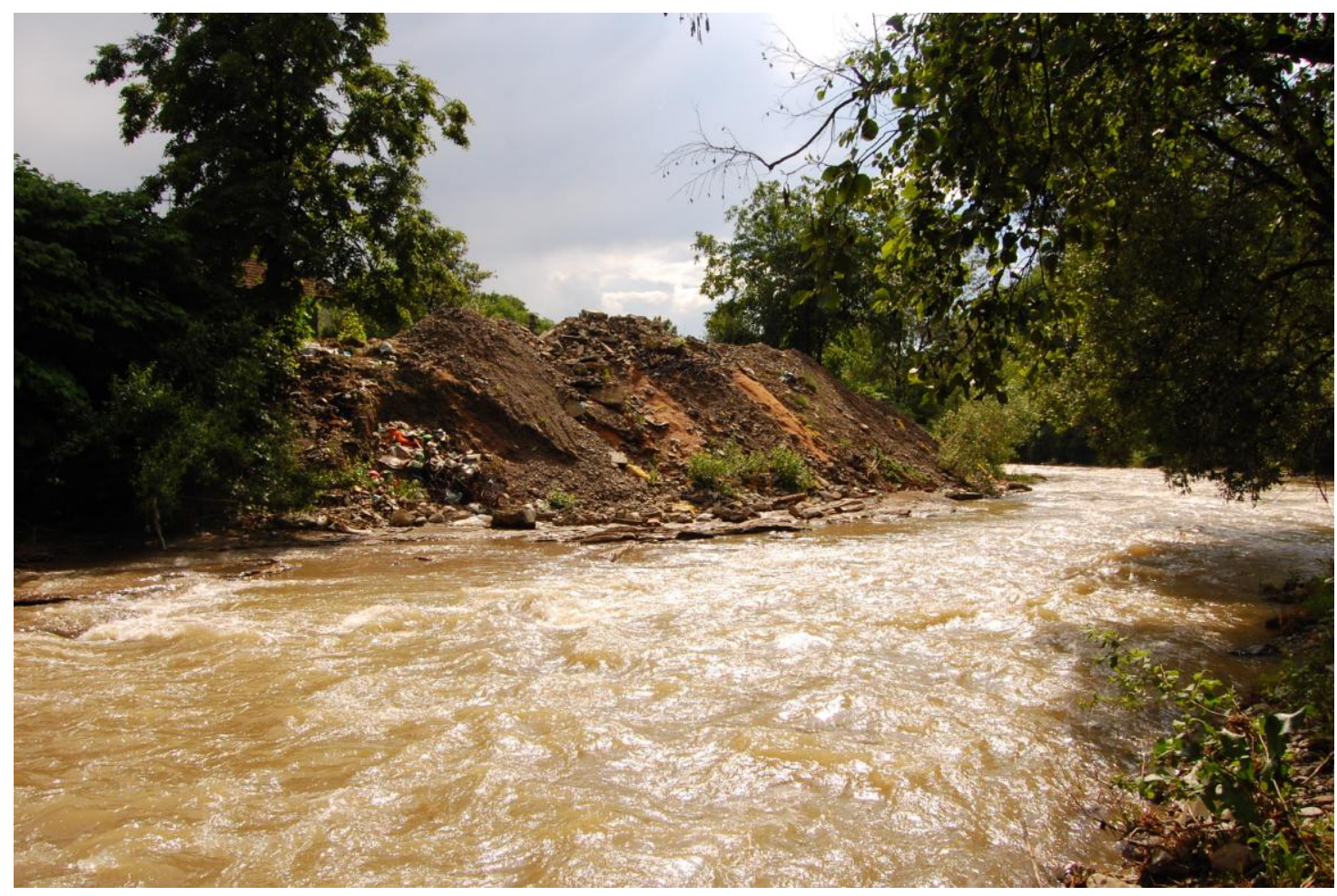

Figure 6. Anthropogenic reduction of the riverine vegetation on Vaser River

\section{Flood washing of fish}

During flood periods, downstream drift of fish is significantly more intense along the channelized and straightened river stretches, as it was noted in all the field campaigns in spring.

\section{Suggested protection measures}

The authors developed specific suggestions for the T. souffia protection measures in the researched basin to compensate for the identified threats.

We underlined the need for the support from the local Maramureş Mountains Nature Park administration based on expanding field activities of the park personnel in order to control and diminish the poaching. The insufficient financial resources for these activities can be somewhat counteracted through cooperative actions with forestry, gendarmerie, and police. It is indisputable that few centralised national/regional institutions, an excellent example in this context being the Romanian National Agency for Fishing and Aquaculture, are not capable of stopping these activities. The establishment of a volunteer corps can also help in controlling this phenomenon, only if 
the involved personnel have the proper specific knowledge in identifying all the fish species and in understanding fish biology and ecology in natural habitats. A simple legitimation cannot replace the needed professional background for this work.

Water engineering interventions and development of low control facilities (dams, bottom sills, dykes, micro hydropower plants, water extractions, riverbed mineral overexploitations, etc.) should not be admitted by Maramureș Mountains Nature Park Scientific Council and Administration without professional environmental impact assessment concerning the effect on the target species and/or their habitats.

The natural-like water flow and sediment transport can be maintained in a state similar to the unregulated conditions, if forestry activities and/or river gravel mining will not significantly alter the self-sustaining natural processes in the river ecosystem. It can be carried out by adapting human activities to the appropriate seasons, when the local natural conditions are relatively similar to those to be generated (i.e. significant turbidity). Seemingly inoffensive, many present (Fig. 7) or potential works on the investigated lotic systems must be of specific management concern. Examples like dams, embankments, fords, bank modifications (Fig. 8), water extractions, alterations of thalwegs, etc., should not be admitted by the local park administrator without the agreement of specialists studying the species of interest, based on the specific/local stressors and the biological and ecological requirements of the species of concern. In this specific case, for example, no ford should be higher than $10-15 \mathrm{~cm}$ in the shallow sectors and dry season. We also propose the all year round control of the forestry activities, like the interdiction of dragging and storage of lumber through/in creeks, streams and rivers. We also propose the control of the development of works for lumber depository and exploitation platforms (Fig. 9) and the obligation of reforestation. In this general context, the planed rotation of forestry activities in the sub-basins of the studied Vișeu Basin is needed.

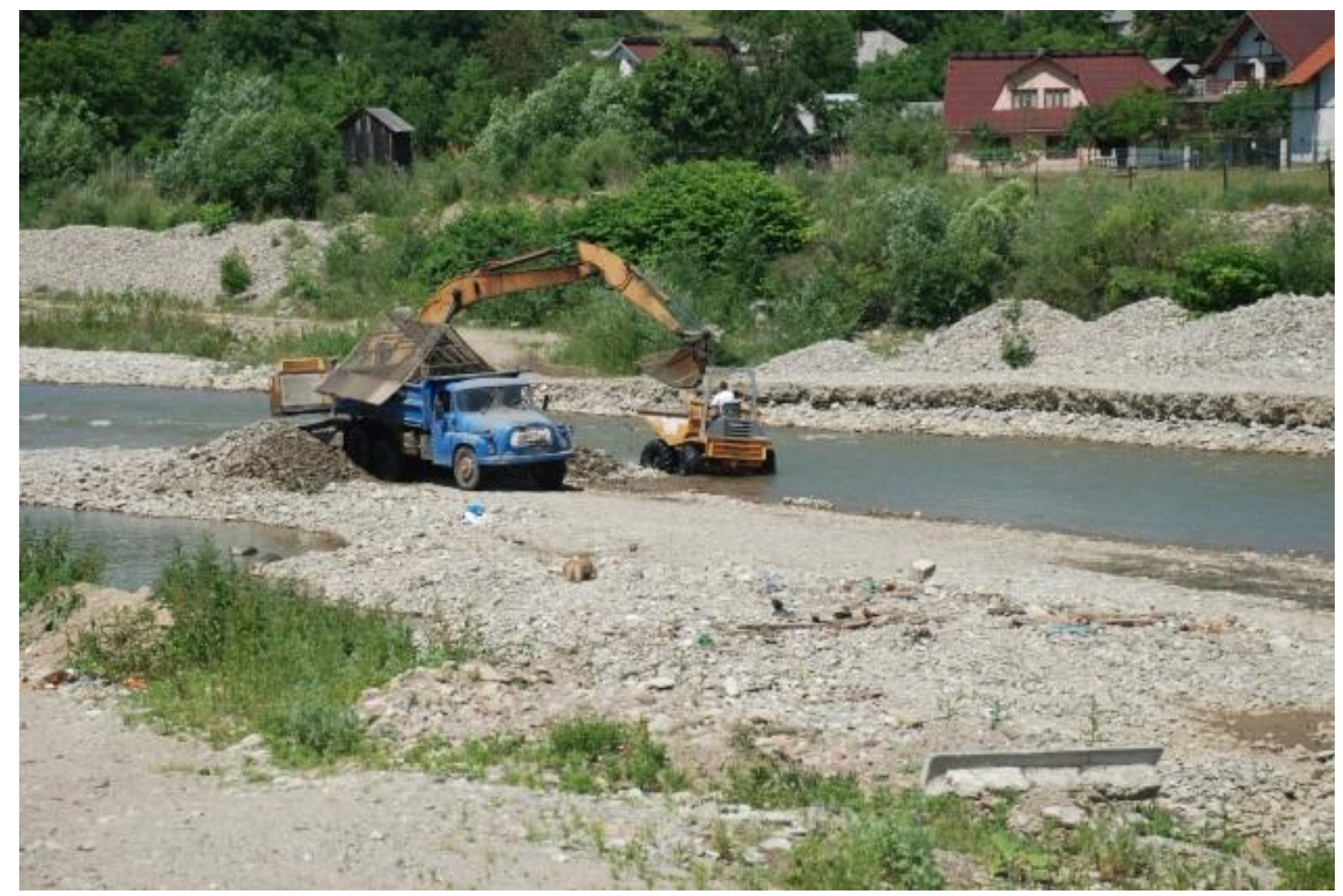

Figure 7. Works in the investigated lotic systems 


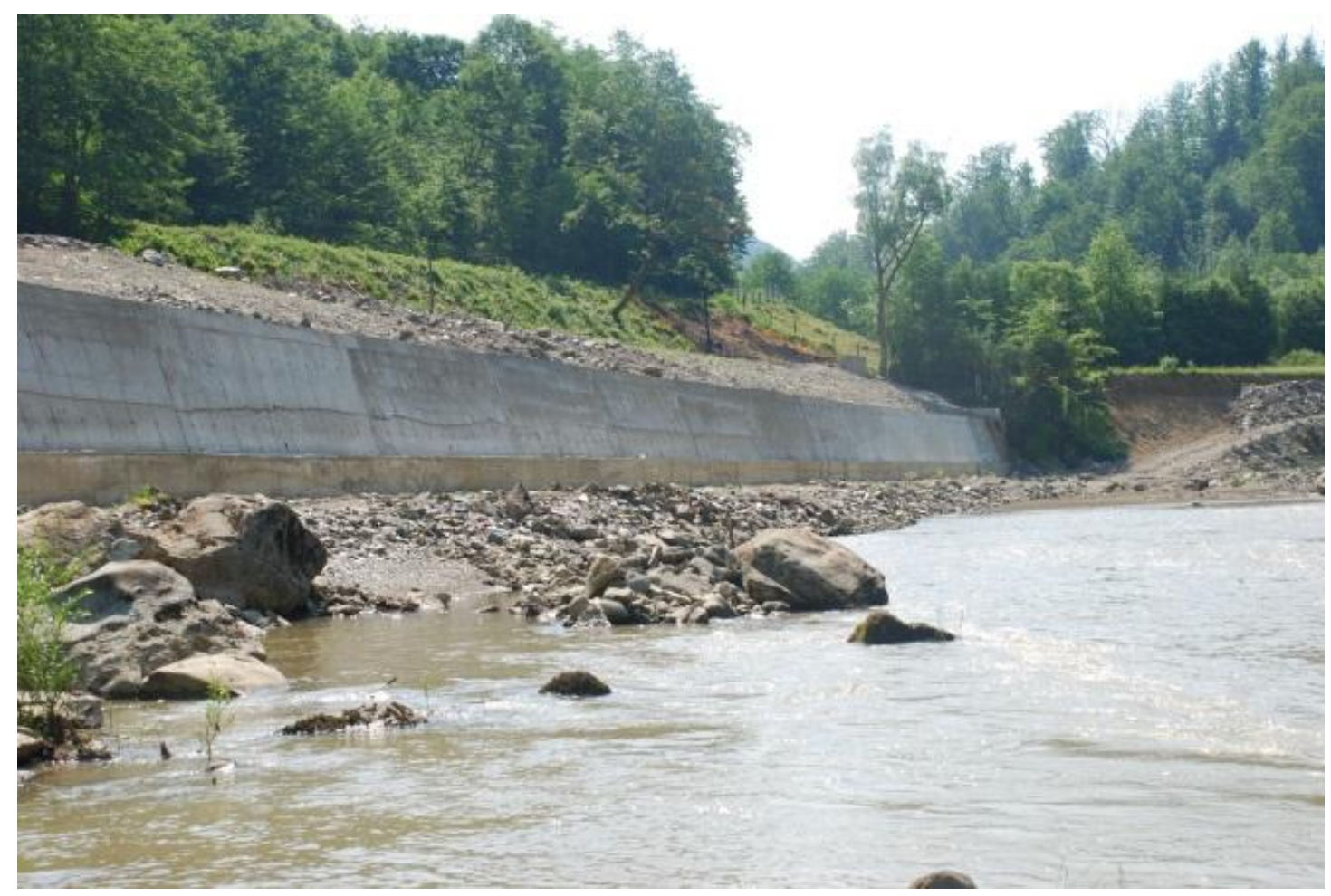

Figure 8. Vişeu River banks anthropogenic modifications

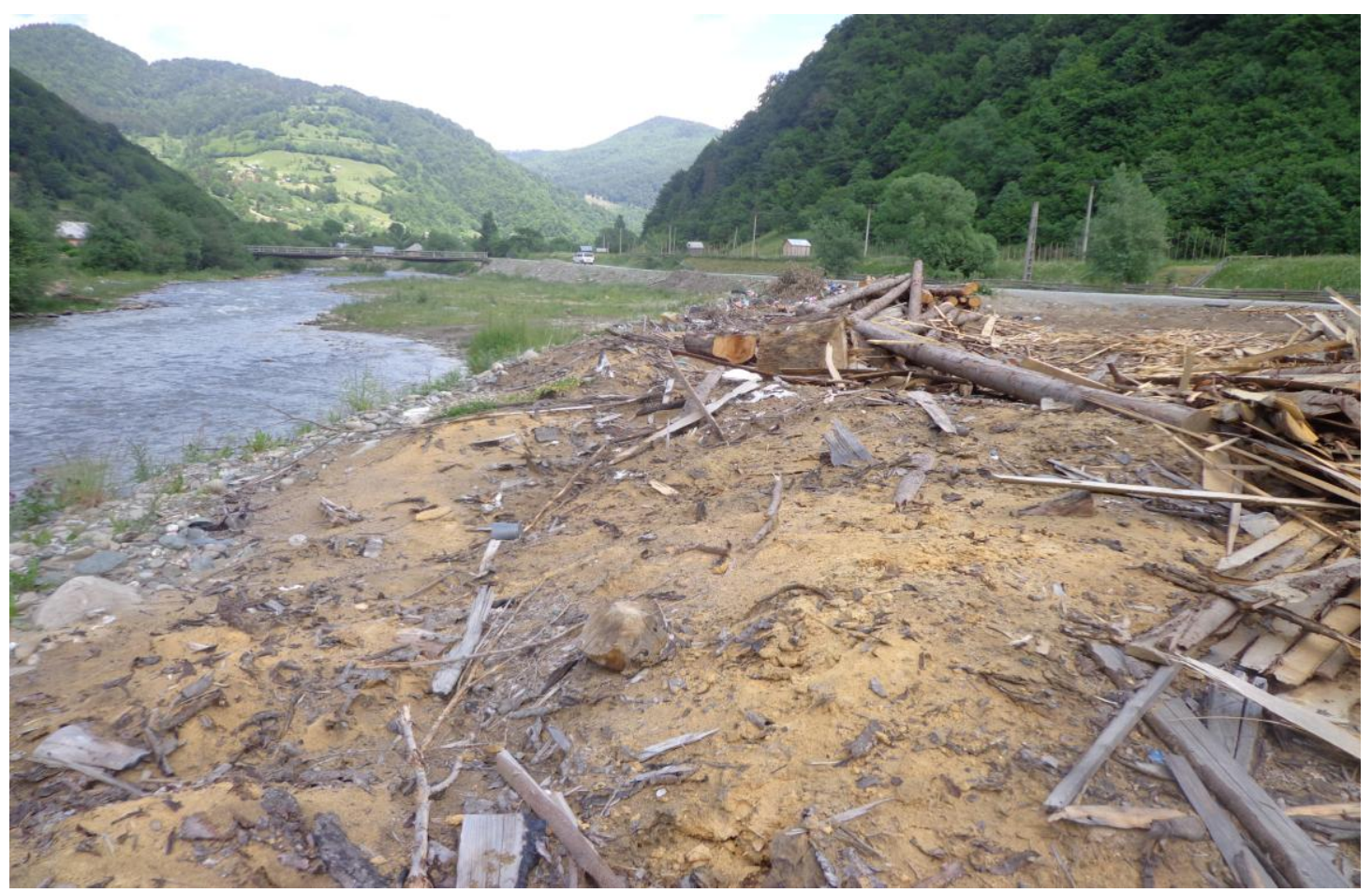

Figure 9. Lumber depository and exploitation platform on Ruscova River 
The restoration and maintenance of longitudinal connectivity, including all the subdrainage basins of the Vișeu Basin, is an important element for conservation of natural habitats.

We propose studying the potential future constructions situated on or near the water courses very cautiously, in the condition in which they could interrupt the longitudinal connectivity along the lotic systems, by different crosswise barriers in the riverbed, and/or by diminishing the water volumes.

The water courses should be not straightened and channelized but kept as much as possible in their natural/semi-natural hydro-geomorphologic state, which provides refuge habitats for fish during floods and reduces the downstream drifting of the aquatic organisms. In the lotic sectors, which are relatively uniform due to river engineering, steps of maximum $15 \mathrm{~cm}$ high should be created, which can provide shelter areas during flood periods.

Combinations of various human pressures affect numerous lotic sectors in the Vişeu Basin (Figs. 4 and 5), and the assessment score for the T. souffia was determined as average.

Some management elements should be enforced in the studied area: poaching control, creation of buffer/refuge sectors on lotic systems; proper management of water use according to seasonal habitat requirements of fish, treatment of sewage and polluted surface waters; recalibration of hydro-energetic utilisation of streams and rivers; integrated management of the Vişeu Basin water resource; creation of lotic systems ecological networks; restoration of longitudinal connectivity in the river system.

T. souffia occurs in other rivers of the Tisa River basin, however, its populations are not abundant like in the past, at least in the Romanian rivers. Its occurrence in the Hungarian section of the Tisa was observed close to the border between Hungary and Ukraine (Harka and Sallai, 2004). On the neighbouring Ukrainian territory, very little information is available on $T$. souffia, because no large-scale ichthyologic surveys were carried out recently and no routine monitoring is performed due to the ban on the use of electrofishing devices for fish sampling in Ukraine. Therefore, the current data on this fish in Ukraine are very fragmentary. This species is listed in the Red Book of Ukraine as vulnerable (Akimov, 2009). T. souffia was mentioned to inhabit middle and upper half of lower reaches of the rivers flowing in the eastern part of the modern Transcarpathian region of Ukraine and was listed as absent in the western part (Vladykov, 1926; 1931) In the middle of the twentieth century, T. souffia was listed as a common species and reported for the upper and middle reaches of the Tisza, Teresva, Tereblia, Rika, and Borzhava rivers, however, it was not detected in Uzh and Latorica rivers (Vlasova, 1956). Nevertheless, this species was found in the Uzh and Latorica rivers as well as in the Teresva, Tereblia, Rika, Borzhava, and Tisza rivers and by Danko (1956), who indicated that this fish was quite abundant in some rivers composing up to $20-30 \%$ of the total catches in abundance. Harka and Bănărescu (1999) recorded this fish in the Tisza River near Vynogradiv in 1995. Later, T. souffia was reported to be sampled in the Tisza, Teresva, and Tereblia rivers but was not detected in the other eight investigated rivers including Rika, Latorica, and Uzh (Koščo et al., 2004). According to Movchan (2011), T. souffia occurs in the Uzh, Latorica, Borzhava, Rika, Tereblia, Teresva, Shopurka, and Tisza rivers as well as in the Tereblia reservoir.

Due to the fact that $T$. souffia populations of the Vişeu and Tisa rivers are interconnected and connections with populations from other Tisa tributaries on the Ukrainian side can be active as well (nevertheless, these connections should be studied 
based on genetic and other alternative methods), special measures to protect $T$. souffia and its habitats should be put into action by the Romanians and Ukrainian authorities, based on transboundary partnership programmes.

\section{Conclusions}

The state of characteristic T. souffia habitats in the Vişeu Basin, and consequently this species populations status are in majority average with only few reduced sectors, and no bad and good sectors from this point of view.

The principle found human impact types, which induced in the degradation of $T$. souffia habitat state in the Vişeu Basin were: poaching, minor changes in riverbed morphodynamics due to river engineering, disruption of water flow and natural sediment transport, destruction of riparian tree and shrub vegetation, habitat fragmentation/isolation of fish populations, organic pollution, and flood washing of fish.

All of these human impact types synergic effects induced a moderate decrease of $T$. souffia distribution and abundance in the last century in the Vişeu Basin.

The survival/thrive of $T$. souffia species populations in this sensible zoogeographical isolated area of its range will depend on an integrated basin long term monitoring and management programmes which should include as a base this study results and proposals.

Acknowledgments. This research was done in the project "Inventarierea, cartarea și evaluarea stării de conservare a speciilor de pești din Parcul Natural Munții Maramureșului (ROSCI 0124 Munții Maramureșului) / Inventory, mapping and assessment of the conservation status of fish species of Munții Maramureșului Nature Park (ROSCI 0124 Maramureșului Mountains)”. Many thanks for the unending backing of the Parcul Natural Munții Maramureșului Administration and Scientific Council members, especially to: Bogdan C., Bucur C., Szabo B., Brener A. and Mărginean M.

\section{REFERENCES}

[1] Akimov, I. A. (ed) (2009): Red Book of Ukraine. Animal World. - Globalkonsalting, Kyiv.

[2] Ardelean, G., Beres, I. (2000): Fauna de vertebrate a Maramureşului. - Ed. Dacia, ClujNapoca.

[3] Bănăduc, D. (2008): Socolău River Basin (Vişeu Watershed) Ichtyofauna, Maramureş Mountains Nature Park (Maramureş, Romania). - Acta Musei Maramorosiensis 7: 498-506.

[4] Bănărescu, P. M. (1964): Fauna R. P. Române, Pisces-Osteichthyes (XIII). - Ed. Academiei Române, București.

[5] Bănărescu, P. M. (2005): Pisces (Peşti). Cartea Roşie a Vertebratelor din România. - Ed. Academiei Române, București. ISBN 973-0-03943-7.

[6] Bănărescu, P. M., Bănăduc, D. (2007): Habitats directive (92/43/EEC). Fish species (Osteichthyes) on the Romanian territory. - Acta Ichtiologica Romanica II: 43-78.

[7] Curtean-Bănăduc, A. (2008): Vişeu River and some tributaries ecological assessment based on macroinvertebrate communities (Maramureş, Romania). - Transylvanian Review of Systematical and Ecological Research 5: 165-182.

[8] Curtean-Bănăduc, A., Schneider-Binder, E., Bănăduc, D. (2014): The Importance of the Riverine Ligneous Vegetation for the Danube Basin Lotic Ecosystems. - In: Cianfaglione, K. (ed.), L'importanza degli Alberi e del Bosco. Cultura, scienza e coscienza del territorio. Temi Ed., Trento, Italia. ISBN: 978-88-973772-63-9. 
[9] Danko, I. A. (1956): Morpho-systematical characteristic of andruga - Leuciscus agassizi (Heckel) of Transcarpathia. - Scientific Letters of Uzhgorod State University, Uzhgorod 21: 101-112.

[10] Didenko, A. V., Velykopolsky, I. I., Buzevich, I. Y. (2011): Illegal fishing in the Tisza River drainage within Ukraine: a threat for local fish stocks? - Archives of Polish Fisheries 19: 249-257.

[11] Didenko, A., Velykopolsky, I., Chuklin, A. (2014): Use of poachers' catches for studying fish fauna in the water bodies of the Transcarpathian region (Ukraine). - Transylvanian Review of Systematical and Ecological Research 16(2): 87-101.

[12] Guti, G., Harka, Á., Sallai, Z. (2014): A magyarországi halfajok természetvédelmi státusza és a halfauna természetvédelmi értékelése. - Pisces Hungarici 8: 19-28.

[13] Halpern, B. S., Frazier, M., Potapenko, J., Casey, K. S., Koening, K., Longo, C., Lowndes, S., Rockwood, R. C., Seling, E. R., Selkoe, K. A., Walbridge, S. (2015): Spatial and temporal changes in cumulative human impacts on the world's ocean. Nature Communications 6:7615. doi:10.1038/ncomms8615.

[14] Harka, A., Bănărescu, P. (1999): Fish Fauna of the Upper Tisza. - In: Hamar, J., SarkanyKiss, A. The Upper Tisza Valley. Tiscia Monograph Series. Szolnok-Szeged-Tîrgu Mureş. Tisza Klub, Szolnok \& Liga Pro Europa, Tîrgu Mureş.

[15] Harka, Á., Sallai, Z. (2004): Magyarország halfaunája - Képes határozó és elterjedési tájékoztató. - Nimfea Természetvédelmi Egyesület, Szarvas.

[16] Koščo, J., Baláz, P., Ivanec, O., Kovalčuk, A., Manko, P., Terek, J. (2004): Príspevok k poznaniu rýb tokov Zakarpatskej oblasti Ukrajiny. - Acta Facultatis Studiorum Humanitatis et Naturae Universitatis Prešoviensis. Prirodne vedy XL: 138-152.

[17] Kottelat, M., Freyhof, J. (1972): Handbook of European Freshwater Fishes. Kottelat. Cornol and Freyhof, Berlin.

[18] Movchan, Y. V. (2011): Fishes of Ukraine. - Zoloti vorota, Kyiv.

[19] Popa, G. O., Curtean-Bănăduc, A., Bănăduc, D., Florescu, I. E., Burcea, A., Dudu, A., Georgescu, S. E. and Costache, M. (2016): Molecular markers reveal reduced genetic diversity in Romanian populations of Brown Trout, Salmo trutta L., 1758, (Salmonidae). - Acta Zoologica Bulgarica 68(3) 399-406. ISSN 0324-0770.

[20] Staicu, G., Bănăduc, D., Găldean, N. (1998): The structure of some benthic macroinvertebrates and fishes communities in the Vişeu Watershed, Maramureş, Romania. - Travaux du Museum National d'Histoire naturelle Grigore Antipa, Bucureşti XL: 587-608.

[21] Vladykov, V. D. (1926): Fishes of Subcarpathian Russia and Methods of Their Capture. Karpatiya, Uzhgorod.

[22] Vladykov, V. D. (1931): Poissons de la Russie souscarpathique (Tchécoslovaquie). Mémoires de la Société Zoologique de France 29: 217-374.

[23] Vlasova, E. K. (1956): Materials on Zakarpattyia ichthyofauna. - Scientific Letters of Uzhgorod State University 16: 3-38. 